\title{
Bacteriological Assessment and Antibiotic Susceptibility Profile of Bacteria Recovered from Clarias gariepinus Selected from Various Fish Farms in Anambra North Senatorial Zones in Anambra State, Nigeria
}

\author{
Chioma M. Ogbukagu*, Chikodili G. Anaukwu, Chito C. Ekwealor, Anthonia N. Mba, \\ Ikechukwu A. Ekwealor \\ Department of Applied Microbiology and Brewing, Nnamdi Azikiwe University, Awka, Nigeria \\ Email: ${ }^{\star}$ Chomy.uzokwe@gmail.com
}

How to cite this paper: Ogbukagu, C.M., Anaukwu, C.G., Ekwealor, C.C., Mba, A.N. and Ekwealor, I.A. (2021) Bacteriological Assessment and Antibiotic Susceptibility Profile of Bacteria Recovered from Clarias gariepinus Selected from Various Fish Farms in Anambra North Senatorial Zones in Anambra State, Nigeria. Advances in Microbiology, 11, 243-256. https://doi.org/10.4236/aim.2021.115018

Received: April 15, 2021

Accepted: May 18, 2021

Published: May 21, 2021

Copyright ( 2021 by author(s) and Scientific Research Publishing Inc. This work is licensed under the Creative Commons Attribution International License (CC BY 4.0).

http://creativecommons.org/licenses/by/4.0/ (c) (i) Open Access

\begin{abstract}
Fishes are cheap sources of protein and are commonly reared in artificial pond in Nigeria. Bacterial infested fishes have been a serious public health concern. This study was aimed at isolating and identifying bacteria associated with the internal organs (gills, liver, guts) of Clarias gariepinus (African Catfish) in fish ponds in Anambra North Senatorial zones in Anambra State, Nigeria, and to determine the seasonal bacterial load of the organs and antibiotic susceptibility profile of the isolates to conventional antibiotics. A total of 720 African catfish were sampled from randomly selected fish farms during rainy and dry seasons. Bacteria isolates inoculated on Blood and Nutrient agar plates were identified based on morphological and biochemical characteristics. Susceptibility of the isolates to antibiotics was carried out using the Kirby-Bauer disc diffusion method. Isolates from the fish organs include species of Vibrio, Aeromonas, Pseudomonas, Lactobacillus, Staphylococcus, Microbacterium, Serratia, Proteus, Bacillus, Streptococcus, Citrobacter and Micrococcus. Results also revealed that there was significant difference ( $\mathrm{p}$ value $<0.05$ ) in the bacterial load recovered from the fish organs, during rainy and dry seasons. Bacillus sp. was the most abundant gram positive bacterium in the organs of the fish samples during the rainy and dry season, while Citrobacter sp., a gram negative organism, was relatively abundant in the liver and gut. Percentage susceptibility of the bacteria to antibiotics was highest with vancomycin (100\%) and least with erythromycin (75.0\%). The most susceptible isolates were species of Staphylococcus, Microccoccus and Microbacterium while Bacillus sp. was the most resistant bacterium. This study has shown
\end{abstract}


that high bacteria load are found in the internal organs of the fish and a good number of the bacteria are resistant to some of the antibiotics tested. There is, therefore, need for adherence to proper sanitary measures to avoid bacterial contamination of fish.

\section{Keywords}

Clarias gariepinus, Antibiotic Susceptibility, Bacteria, Fish Organs

\section{Introduction}

In many countries, fish is consumed and is considered to be a good source of dietary protein. Fish and fish-products are important not only from a nutritional point of view but also as an item of international trade and foreign exchange earnings for a number of countries in the world [1]. On a global scale, they are the most important source of protein, and is estimated that more than $30 \%$ of fish for human consumption comes from aquaculture [1]. The fisheries and aquaculture sector significantly expanded in the past decades, and total production, trade and consumption reached an all-time record of 179 million tonnes in 2018 [2]. The top fish producers are China and Indonesia, accounting for almost 50 percent of total global capture production [2]. Over the past 35 years, aquaculture production in Nigeria has grown by 12 percent annually, from a little over 6000 metric tons in 1980 to nearly 307,000 metric tons in 2016 [3]. Nigeria is the largest fish producer in sub-Saharan Africa, accounting for 52 percent of the total farmed fish production in the region [4].

Clarias gariepinus is freshwater fish species of African origin and is one of the most cultured species in the world. This fish species is valuable for fish farming (aquaculture) due to its easy to farm especially in warm climates, fast growth rate, resistance to diseases, and high stocking density [5]. Fishes are reared in different water culture media or confinement such as concrete, earthen or plastic ponds. Concrete and earthen ponds have been the widely used culture system for fish [6]. Fishes reared in these environments are contaminated by both pathogenic and opportunistic microorganisms. Fish contamination can be linked to raw material, personnel, processing tools such as forklifts through leakage, opening in building and pests [1].

Fish take a large number of bacteria into their gut from water sediment and food [7]. These microbes exist in the aquatic environment and they enter the digestive tract of fish and form commensal intestinal microbiota inside the intestine [8]. The tissue of a healthy fish is normally considered sterile until after bacterial invasion which leads to spoilage [1]. According to Reference [9], the normal bacterial load of the surface slime of fish range from $10^{2}-10^{7} \mathrm{cfu} / \mathrm{cm}^{2}$ while the gills and intestines range up to $10^{3}-10^{7} \mathrm{cfu} / \mathrm{g}$. The microbial load increases with increasing temperature and results in rapid fish spoilage [10]. According to Reference [11], working on microbial load of smoked-dried fishes 
observed that the mean total bacterial count from the fish samples was significantly higher in rainy season than in dry season.

Although only a few infectious agents in fish are able to infect humans, some exceptions exists that may result in fatalities [12]. However the greatest risk to human health is due to the consumption of raw or insufficiently processed fish and fish products [12]. Bacteria found on African Catfish majorly belong to genera of Pseudomonas, Staphylococcus, Flavobacterium, Vibrio, Micrococcus, Bacillus and Aeromonas. Some exist as microflora in pond water and large water bodies. These bacteria can be found on the gills, skin, fin or in the intestinal tracts of fish under normal conditions but due to environmental stress they may produce epizootics diseases while some are also pathogenic organisms [13].

Knowledge about antibiotic susceptibility of bacteria is vital for the proper management of the diseases they cause. Some of these microorganisms possess resistant determinant which enhances their potentials for infecting consumers. For instance, Escherichia coli is known to survive well in aquatic environments, highly adept at horizontal gene transfer and a notorious vehicle for antibiotic resistance dissemination [6]. Reference [14] reported up to $100 \%$ resistance against various antibiotics in fish farms and [15] observed multiple resistance in fish. The number of infections caused by antibiotic resistant bacteria in fish is rising worldwide [16].

The aims of the study was to isolate and identify bacteria associated with the gut, gill and liver of African fish (Clarias gariepinus); determine the seasonal bacterial load of the fish and evaluate the antibiotic susceptibility profile of the isolates on selected antibiotics.

\section{Materials and Methods}

\subsection{Description of Study Area}

The study area was Anambra North Senatorial zones, one of the three senatorial zones in Anambra state of Nigeria. It covers an area approximately $4416 \mathrm{~km}^{2}$ [17], and lies at Latitude of $6^{\circ} 20^{\prime} \mathrm{N}$ and longitude $7^{\circ} 00^{\prime} \mathrm{E}$. Fish samples were obtained randomly from twenty fish farms from Anambra State.

\subsection{Description of the Sampled Fish Ponds}

All the sampled fish ponds were open ponds with a carrying capacity of 100 1000 fishes per time, made of concrete with varying dimensions. The source of water for running the pond was bore holes which were built within the farm. The spent fish pond waters are mostly removed fortnightly through an opening properly channeled to drainage system. African Catfish (Clarias gariepinus) was the only fish held in these ponds.

\subsection{Collection of Fish Samples}

A total of 720 fishes of Clarias gariepinus (African catfish) were aseptically collected from the fish farm sites between the periods of May to October 2016 
(Rainy season) and November to April, 2017 (Dry season). The fishes were transported in a sterile polythene bag to the laboratory for further examination. All samples collected were processed and analysed within $3 \mathrm{~h}$ of collection.

\subsection{Preparation of Stock Cultures from Fish}

The fishes were observed, to note external symptoms. Weight of each fish was measured using weighing balance of $0.01 \mathrm{~g}$ sensitivity. Fish gills, gut and liver were harvested aseptically with the aid of sterile dissecting blades and forceps, and were transferred into properly labeled sterile containers for microbiological analysis. Ig of the dissected gill was macerated in $9 \mathrm{ml}$ of sterile distilled water. This was vigorously shaken for $1 \mathrm{~min}$ and allowed to stand for $5 \mathrm{~min}$. The gut and liver of the fish were similarly treated. They served as the stock culture.

\subsection{Enumeration and Isolation of Bacterial Organisms in Fish Samples}

A 10-fold serial dilution of the original stock culture of the gills of the fish was prepared. A $0.1 \mathrm{ml}$ of $10^{-4}$ dilution was inoculated onto sterile Blood and $\mathrm{Nu}$ trient agar (Oxoid) plate using spread plate technique and incubated at $37^{\circ} \mathrm{C}$ for $24 \mathrm{~h}$. Developed colonies were counted and subcultured on freshly prepared sterile Nutrient agar plate to obtain pure cultures which were stored at $4^{\circ} \mathrm{C}$ for further studies. The gut and liver of the fish were similarly treated.

\subsection{Identification of the Bacterial Isolates from Fish Samples}

The bacterial isolates were characterized based on their morphological and biochemical characteristics as described by Bergey's Manual of Determinative Bacteriology [18]. Biochemical tests carried out include Gram reaction, motility, indole, methyl red, Voges-Proskaeur, citrate utilization, catalase, oxidase and sugar fermentation tests.

\subsection{Frequency of the Bacterial Isolates from the Fish Samples}

The percentage frequency of the bacterial isolates from the gills, liver and gut of the fish samples were determined. This was calculated from:

$$
\text { Percentage frequency }(\%)=\frac{\text { Frequency of occurrence }}{\text { Total number of occurrence }} \times 100
$$

\subsection{Antibiotic Susceptibility Tests of the Bacterial Isolates from Fish Samples}

Susceptibility of the bacterial isolates to conventional antibiotics was carried out using the Kirby-Bauer disc diffusion method on Muller-Hinton agar with $0.1 \mathrm{ml}$ of standardized bacterial suspension (1.0 McFarland standard) [19]. A loopful of the standardized inocula $\left(3.0 \times 10^{8} \mathrm{cfu} / \mathrm{ml}\right)$ was spread inoculated onto sterile Mueller Hinton agar plate, allowed to dry and the antibiotic discs placed on it using a sterile forcep. Antibiotics tested were randomly selected and include Vancomycin $(30 \mu \mathrm{g})$, Trimethoprim $(75 \mu \mathrm{g})$, Ciprofloxacin $(5 \mu \mathrm{g})$, Gentamycin 
$(10 \mu \mathrm{g})$, Streptomycin $(10 \mu \mathrm{g})$, Oxytetracycline $(10 \mu \mathrm{g})$, Ampicillin $(10 \mu \mathrm{g})$ and Erythromycin $(15 \mu \mathrm{g})$. The plate was incubated at $37^{\circ} \mathrm{C}$ and the zones of growth inhibition around the antibiotic discs were measured after $24 \mathrm{~h}$. The result was interpreted as resistant or susceptible according to the Clinical and Laboratory Standards Institute guidelines [20].

\subsection{Statistical Analysis}

Univariate and One way analysis of variance were used to analyze the data obtained using SPSS version 21 [21].

\section{Results}

\subsection{Enumeration and Isolation of Bacterial Organisms in Fish Samples}

The mean bacterial count obtained from the gill, liver and gut of the fish samples during dry and rainy season are presented in Figures 1-3. The counts obtained from the gills (Figure 1) ranged from $1.3 \times 10^{3}-7.9 \times 10^{3} \mathrm{cfu} / \mathrm{g}$ in dry season and $1.3 \times 10^{3}-9.6 \times 10^{3} \mathrm{cfu} / \mathrm{g}$ in rainy season, while the counts obtained in the liver (Figure 2) during dry and rainy seasons ranged from $1.7 \times 10^{2}-7.0 \times 10^{2}$ $\mathrm{cfu} / \mathrm{g}$ and $2.6 \times 10^{2}-6.3 \times 10^{2} \mathrm{cfu} / \mathrm{g}$ respectively. Bacterial counts obtained from the fish gut (Figure 3) ranged from $1.93 \times 10^{3}-6.47 \times 10^{3} \mathrm{cfu} / \mathrm{g}$ in dry season and $2.07 \times 10^{3}-7.17 \times 10^{3} \mathrm{cfu} / \mathrm{g}$ in rainy season. As can be observed from Figures 1-3, the mean bacterial load were higher in the gills and guts during the rainy season while it was higher in the liver during the dry season. The bacterial load in the liver (Figure 2) is lower than those observed in the gills (Figure 1) and guts (Figure 3) during rainy and dry seasons. However, from the fish samples, the highest bacterial load was observed in the gut during the rainy season. Univariate analysis of variance of the bacterial counts shows that there was significant difference $(\mathrm{P}$ value $<0.05)$ in the counts obtained between the gills, liver and guts of the fish samples and during dry and rainy seasons.

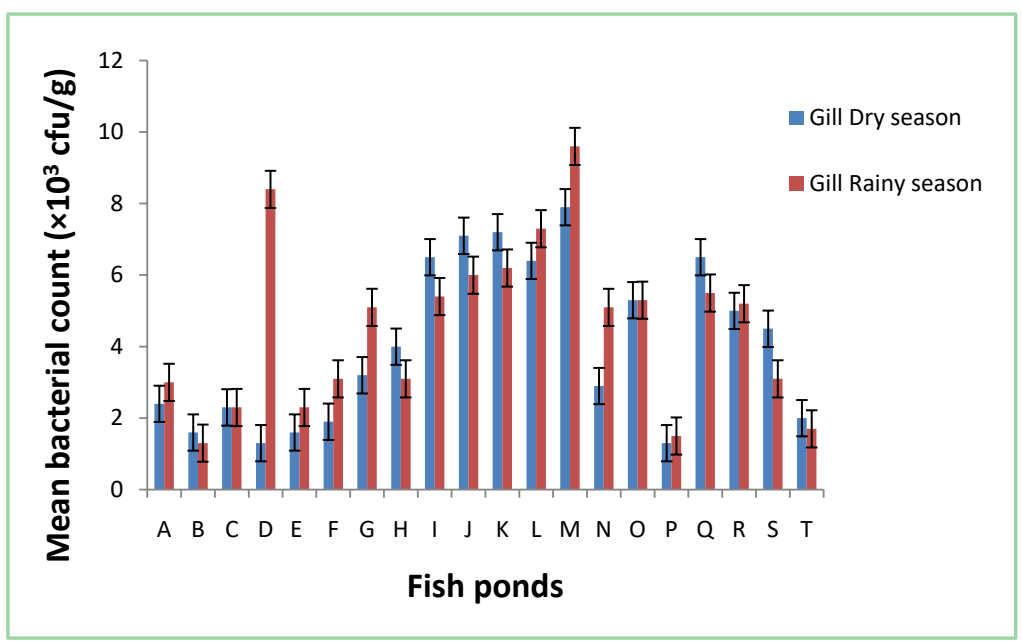

Figure 1. Mean bacterial count in gills of fish samples. 


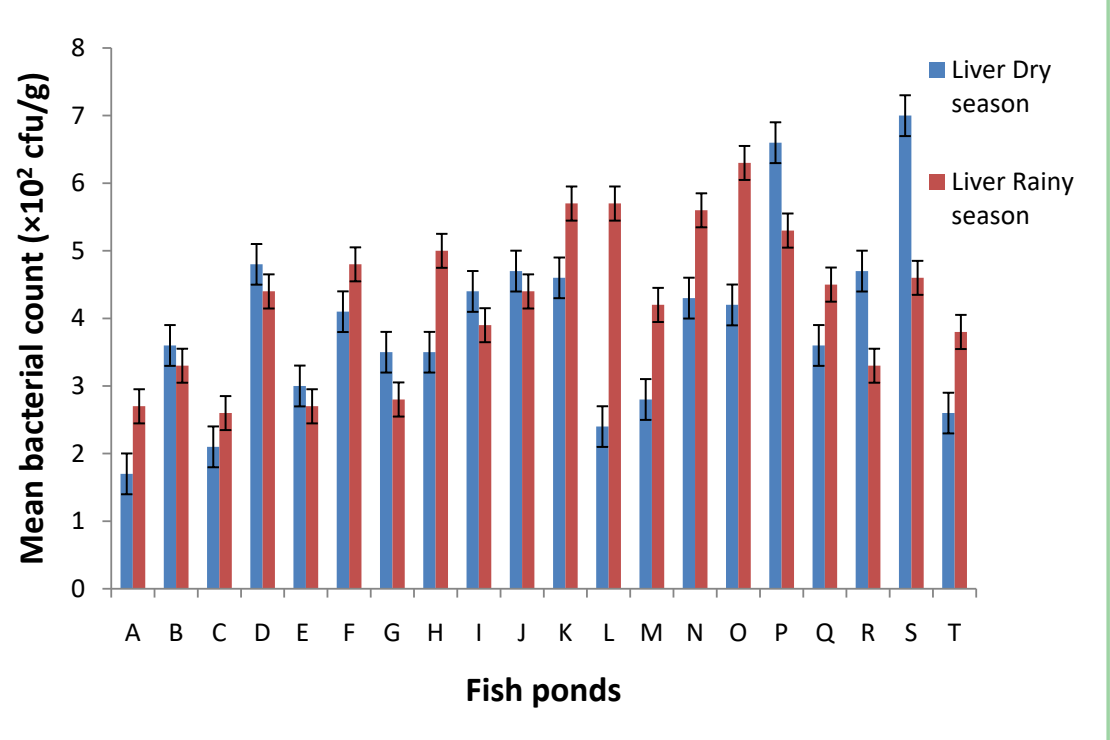

Figure 2. Mean bacterial count in the liver of fish samples.

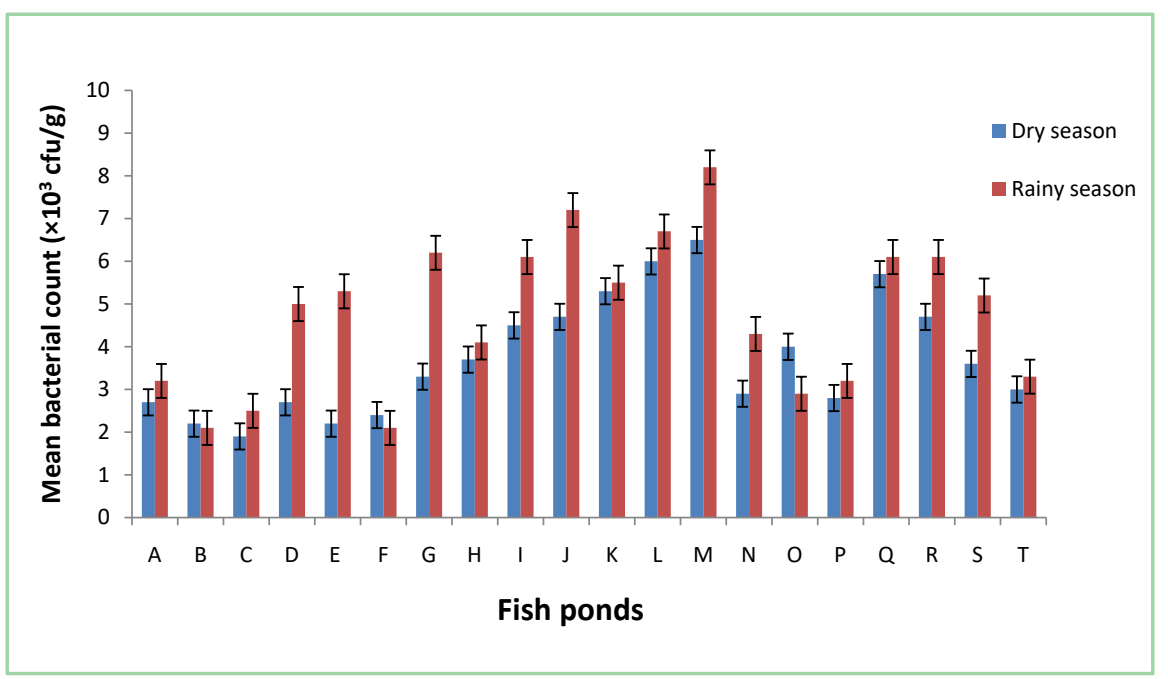

Figure 3. Mean bacterial count in the gut of fish samples.

\subsection{Identification of Bacterial Isolates from Fish Samples}

Out of the 720 fish samples from the fish ponds, a total of 12 genera of bacterial isolates were identified and they include Vibrio, Aeromonas, Pseudomonas, Lactobacillus, Staphylococcus, Microbacterium, Serratia, Proteus, Bacillus, Streptococcus, Citrobacter and Micrococcus (Table 1). Figure 4 and Figure 5 show the percentage occurrence of the bacterial isolates from the gills, liver and guts during rainy and dry seasons. As can be observed (Figure 4 and Figure 5), Bacillus sp was the most abundant gram positive bacterium found in the three organs of the fish samples during rainy and dry seasons. Citrobacter sp., a gram negative bacterium, was observed to be relatively in abundance in the liver and gut of the fish samples during rainy and dry seasons. 


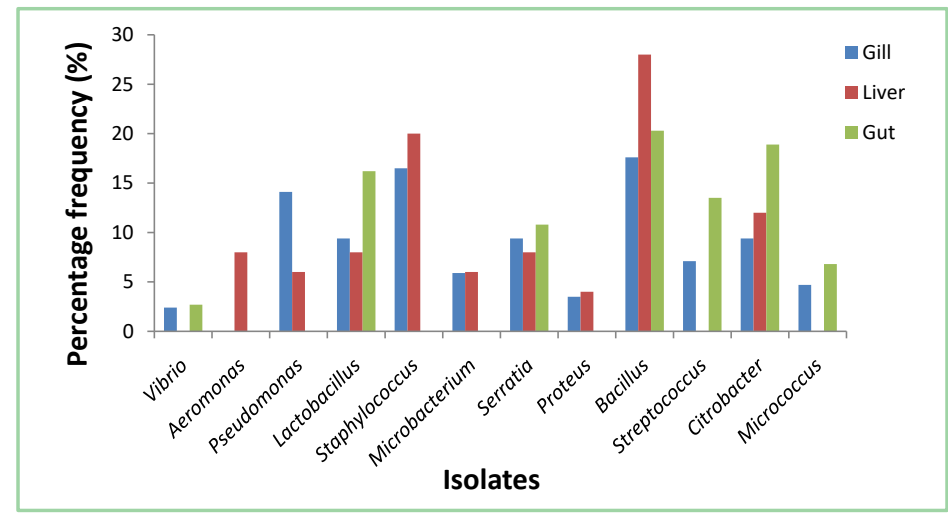

Figure 4. Percentage occurrence of the bacterial isolates during rainy season.

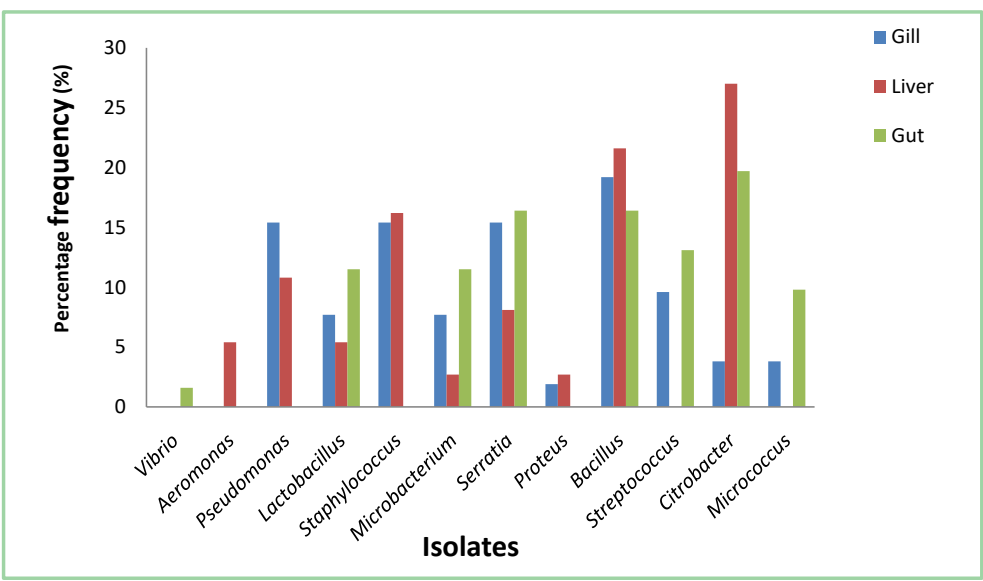

Figure 5. Percentage occurrence of the bacterial isolates during dry season.

Table 1. Biochemical tests of bacterial organisms isolated from the organs of fish samples.

\begin{tabular}{|c|c|c|c|c|c|c|c|c|c|c|c|c|}
\hline \multicolumn{13}{|c|}{ Isolates } \\
\hline Biochemical tests & $1 \mathrm{~F}^{\mathrm{gt}}$ & $2 \mathrm{~F}^{\mathrm{gt}}$ & $3 \mathrm{~F}^{\mathrm{gt}}$ & $4 \mathrm{~F}^{1}$ & $5 \mathrm{~F}^{\mathrm{gl}}$ & $6 \mathrm{~F}^{\text {glt }}$ & $7 \mathrm{~F}^{\mathrm{gl}}$ & $8 \mathrm{~F}^{\mathrm{glt}}$ & $9 \mathrm{~F}^{\mathrm{glt}}$ & $10 \mathrm{~F}^{\mathrm{glt}}$ & $11 \mathrm{~F}^{\mathrm{gl}}$ & $12 \mathrm{~F}^{\mathrm{glt}}$ \\
\hline Gram reaction & $-\mathrm{ve}$ & $+\mathrm{ve}$ & $+\mathrm{ve}$ & $-\mathrm{ve}$ & ve & $+\mathrm{ve}$ & $+\mathrm{ve}$ & +ve & -ve & -ve & $-\mathrm{ve}$ & $+\mathrm{ve}$ \\
\hline Shape & Rod & Cocci & Cocci & Rod & Rod & Rod & Cocci & Rod & Rod & Rod & Rod & Rod \\
\hline Motility & + & - & - & + & + & + & - & + & + & + & + & - \\
\hline Indole & + & - & - & + & - & - & - & + & - & - & - & - \\
\hline Methyl Red & - & - & - & - & - & - & + & + & - & + & + & - \\
\hline Voge P & + & - & + & - & - & + & + & - & + & - & - & - \\
\hline Citrate & + & - & + & + & + & + & + & - & + & + & + & - \\
\hline Spore & - & - & - & - & - & + & - & - & - & - & - & - \\
\hline Catalase & - & - & + & + & + & + & + & + & + & + & + & - \\
\hline Oxidase & + & - & + & + & + & - & - & - & - & - & - & - \\
\hline Coagulase & - & - & - & - & - & - & + & - & - & - & - & - \\
\hline \multicolumn{13}{|l|}{ Sugar fermentation } \\
\hline Lactose & + & + & - & + & + & + & + & + & - & + & - & + \\
\hline Mannitol & + & - & - & + & + & + & + & + & + & + & - & - \\
\hline Sucrose & + & + & - & + & + & + & + & + & + & + & - & + \\
\hline Arabinose & - & - & - & + & + & - & - & - & - & + & - & + \\
\hline Maltose & + & + & - & + & + & + & + & + & + & + & - & + \\
\hline Glucose & + & + & + & - & - & + & + & + & + & + & + & + \\
\hline
\end{tabular}

Key: $1 \mathrm{~F}=$ Vibrio sp., $2 \mathrm{~F}=$ Streptococcus sp, $3 \mathrm{~F}=$ Micrococcus sp., $4 \mathrm{~F}=$ Aeromonas sp., $5 \mathrm{~F}=$ Pseudomonas sp., $6 \mathrm{~F}=$ Bacillus sp., $7 \mathrm{~F}=$ Staphylococcus $\mathrm{sp} ., 8 \mathrm{~F}=$ Microbacterium sp., $9 \mathrm{~F}=$ Serratia sp., $10 \mathrm{~F}=$ Citrobacter $\mathrm{sp}$., $11 \mathrm{~F}=$ Proteus $\mathrm{sp} ., 12 \mathrm{~F}=$ Lactobacillus sp. Isolates with superscript "g" were from the fish gill; "l" from the fish liver only; "gl" from fish gill and liver; "gt" from the fish gill and gut; "glt" from the fish gill, liver and gut. 


\subsection{Antibiotic Susceptibility Tests of the Bacterial Isolates from Fish Samples}

Table 2 shows the antibiotic susceptibility tests of the bacterial isolates. Staphylococcus sp, Micrococcus sp and Microbacterium sp. showed 100\% susceptibility to the antibiotics tested, while Bacillus sp. had the least susceptibility (62.5\%). Percentage susceptibility of the bacterial isolates was highest with vancomycin (100\%), and least with erythromycin (75\%).

\section{Discussion}

Fish farming in artificial ponds is a common practice in some parts of Anambra state as a means of ensuring constant supply of fishes. Fish in their natural habitat may not be free from bacteria infestation but the rate however is highly dependent on some key environmental and climatic factors as well as the species of fish and bacteria [22]). Certain environmental factors tend to encourage the rate of infestation while others instead affect bacteria survival and development negatively [22]. The timings of bacteria infestation on fish is also to some extent controlled by seasonal changes with the consequent changes in climatic conditions [22]. Considering the findings from the artificial fish habitat it may be concluded that the presence of these bacteria in skin and gills may be attributed to poor sanitary conditions under which the fishes are cultured in the ponds.

The seasonal variation of the bacterial load in the internal organs of fish samples obtained from different fish farms in Anambra state (Figures 1-3), showed that bacterial load was higher during rainy season than during dry season. The bacterial load in the gill of the fish samples was higher than the counts obtained in the gut and liver in both dry and rainy seasons.

The high bacterial load in the gill, liver and gut (Figures 1-3) of fishes observed during the rainy season in this study could be attributed to cool atmospheric environment and pond water temperature, which is conducive for proliferation of mesophilic organisms. At increased weather temperature, during the dry season, microbial counts of the fishes in open ponds are adversely affected. This view supports the work of [23], who reported high microbial load in fresh Engraulicypris sardella (Usipa) during the rainy season than in the dry season. Similarly, [11], recorded a significantly higher mean total bacterial count during the rainy season than in the dry season, in their comparative analysis of the microbial load of smoke-dried fishes (Ethmalosa fimbriata and Pseudotolithus elongatus) sold in Oba and Koko markets in Edo and Delta States, Nigeria. Contrary to our findings, [24] reported a high microbial load in fishes during the dry season than in rainy season. They observed that freshwater fish in ponds commonly suffer from bacterial diseases such as various kinds of skin ulcerations, albinoderma, erythroderma, furunculosis, and verticle-scale disease, primarily caused by Aeromonas sp. and Pseudomonas sp. However, bacterial load of fishes depends on the microbial flora and sanitary conditions of the fish pond water, whether dry season or rainy season. 


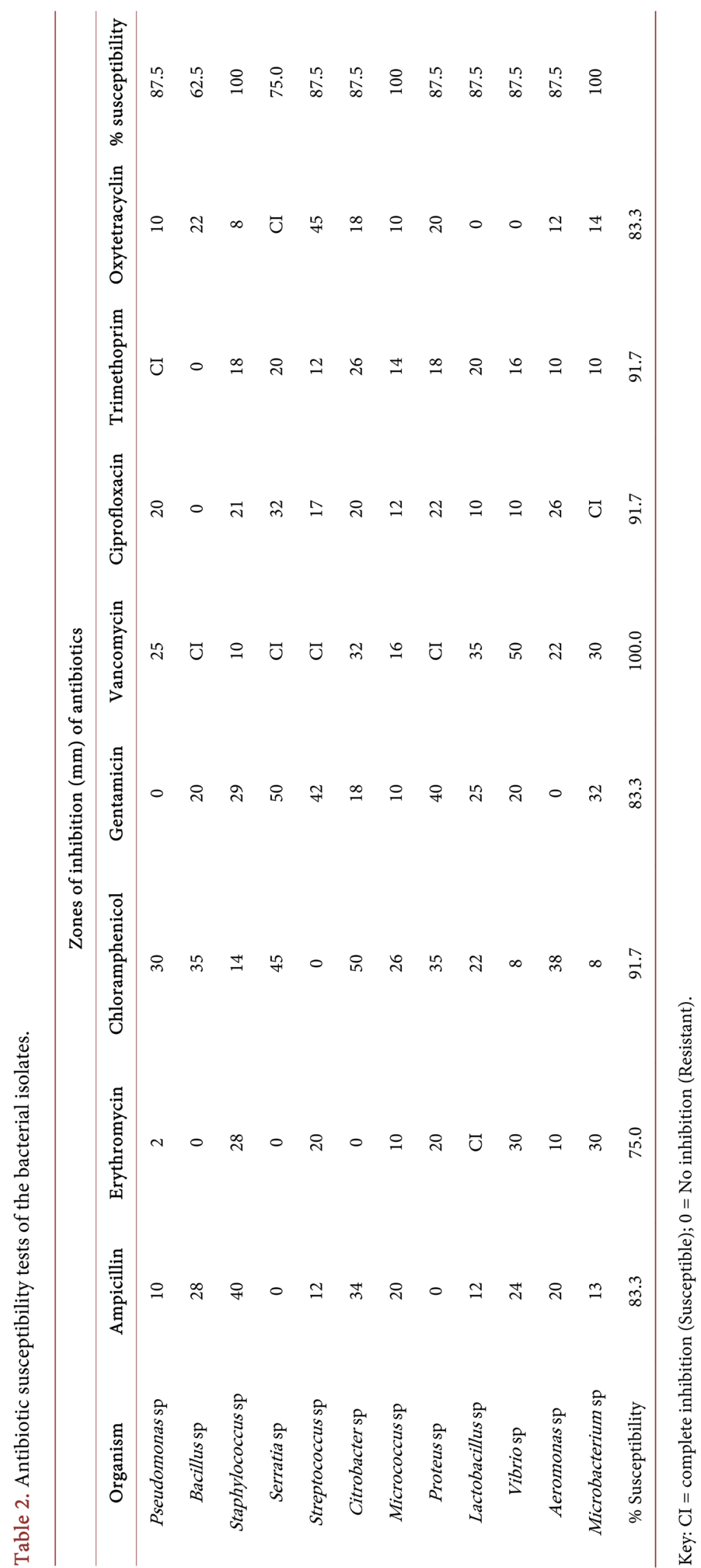


The bacterial load recorded in the gills (Figure 1), was significantly higher ( $\mathrm{P}$ value $<0.05)$ than that recovered from other organs. This may be due to the fact that gills play an important role in filtering microscopic organisms while in water, and these smaller particles entrapped by the gill filaments in a mucous lead to higher level of bacterial population. This observation is in line with the work of [25], who reported high bacterial count in the gills than in other organs sampled. They recorded counts ranging from $0.73 \pm 0.0030 \times 10^{3}-2.55 \pm 0.0128 \times$ $10^{3} \mathrm{cfu} / \mathrm{g}$. Similar range of bacterial count was recorded by [5], during their work on microbiota of catfish (Clarias gariepinus) tissues, and opined that the higher microbial load in gills than liver and intestine is due to the gill's constant interaction with the water environment. On the contrary, very high bacterial load of $12.10 \pm 0.42 \times 10^{12} \mathrm{CFU} / \mathrm{g}$ in the intestine, followed by gill $\left(12.10 \pm 0.42 \times 10^{12}\right.$ $\mathrm{CFU} / \mathrm{g})$ and least in the liver $\left(6.48 \pm 1.06 \times 10^{6} \mathrm{CFU} / \mathrm{g}\right)$ of Tilapia was reported by [26], during their work on prevalence and antimicrobial susceptibility of pathogenic bacteria in Nile Tilapia, Oreochromis niloticus L. They also noted that poor sanitary conditions could have been the cause of such high load. Similarly, [27] reported that the intestine of fish is heavily colonized by heterotrophic bacteria. Reference [28], reported high bacterial loads in guts than observed in the skin. Reference [29], also noted high bacterial load in the gut when compared to the skin and gills.

The bacteriological analysis of the internal organs of fish samples revealed the presence of several bacterial genera. Table 1 and Figure 4 and Figure 5 shows the percentage occurrence of the bacterial isolates during rainy and dry seasons. The bacterial isolates recovered in this study are in line with the work of other researchers [30] [31]. The high prevalence rate of Bacillus spp. in the fish organs during both seasons observed in this study supports the work of [30]. They reported in their work on isolation, characterization and antibiotic resistance profile of bacteria from the gut of African catfish that Bacillus spp. was the most occurring bacteria. Similarly, in the work of [32], Bacillus spp. had the highest percentage occurrence. The high occurrence of Bacillus sp. in the fish organs during both seasons could be due to their high adaptability to such environments. Bacillus spp being spore formers can adapt to very harsh conditions. $C i$ trobacter sp, a gram negative bacterium, was found to have the highest percentage occurrence in fish liver and gut during the dry seasons (Figure 4 and Figure 5). This finding supports the work of [33], in their study on diversity of enterobacteriaceae retrieved from diseased cultured Oreochromis niloticus. They recorded the highest percentage prevalence of Citrobacter sp $(26.74 \%)$ in the internal organs of the fish especially in the liver. Contrary to our findings, [31], in their work on isolation and identification of bacteria flora from catfish, noted that Aeromonas sorbia was the most occurring bacteria. The low prevalence of Vibrio sp. and Proteus sp. observed in this study (Figure 4 and Figure 5) is in line with the work of [34]. In their study on the preliminary survey of gramnegative bacteria pathogens from commonly caught fish species (Oreochromis 
niloticus, Cyprinus carpio and Clarias gariepinus), they recorded a low prevalence of species of Vibrio and Proteus. However, [35] reported a high prevalence of Vibrio sp. in their study on aerobic bacterial flora of common carp (Cyprinus carpio L.) cultured in earthen ponds in Saudi Arabia. Reference [36], also worked on bacterial microflora of fish and reported that the liver and kidney of healthy turbot were highly populated by mostly Pseudomonas and Vibrio including V.fischeri, V. harveyi, V. Pelagius, and V. splendidus.

The increasing rate of antibiotic resistance among livestock-associated organisms has raised serious public health concern [16]. The bacterial isolates in this study, showed varying susceptibility and resistance to the antibiotics tested (Table 2). All the isolates were susceptible to vancomycin, but showed highest resistance to erythromycin (75\%). Contrary to our findings, [32], observed a $100 \%$ resistance to erythromycin from organisms isolated during their work on microbial evaluation and occurrence of antidrug multi-resistant organisms among the indigenous Clarias species in River Oluwa, Nigeria. The susceptibility of all the bacterial isolates to vancomycin as recorded in this study is similar to the works of [37] and [38]. While [37] recorded that all the isolates from fish samples in China were susceptible to vancomycin, cephalexin and florfenicol, [38], observed a high susceptibility of the bacterial isolates from Nile Tilapia to vancomycin alongside ampicillin, chloramphenicol and ciprofloxacin. Reference [39], also reported varying levels of susceptibility to vancomycin, nitrofurantoin, azithromycin, gentamicin and levofloxacin by bacterial isolates from infected fishes. Highest resistance of the bacterial isolates to the antibiotics tested was observed in Bacillus sp. Staphylococcus sp., Micrococcus sp and Microbacterium sp. showed 100\% susceptibility while Pseudomonas sp., Streptococcus sp., Citrobacter sp., Proteus sp., Lactobacillus sp., Vibrio sp. and Aeromonas sp. were resistant to only one antibiotic (Table 2). The resistance of the isolates to antibiotics could be attributed to indiscrimate use of these antibiotics in aquaculture.

Rearing of fishes in artificial ponds has been observed to contain large population of bacteria, some of which are opportunistic pathogens to fish and man. The bacterial load in the fish organs varied with season, and has been observed to be higher in the gills than in the other organs sampled. Bacillus sp was the most resistant bacterium to the antibiotics tested while erythromycin was the most resisted antibiotic.

\section{Conflicts of Interest}

The authors declare no conflicts of interest regarding the publication of this paper.

\section{References}

[1] Danba, E.P., Bichi, A.H., Ishaku, S., Ahmad, M.K., Buba, U., Bingari, M.S., Barau, B.W. and Fidelis, U.F. (2014) Occurrence of Pathogenic Bacteria Associated with Clarias gariepinus Selected Fish Farms of Kumbotso Local Government Area of Kano State, Nigeria. Bayero Journal of Pure and Applied Sciences, 7, 145-149. 
https://doi.org/10.4314/bajopas.v7i2.25

[2] Food and Agricultural Organization (FAO) (2020) The State of World Fisheries and Aquaculture. Sustainability in Action. Food and Agriculture Organization of the United Nations, Rome.

[3] WorldFish (2018) WorldFish Nigeria Strategy: 2018-2022. http://pubs.iclarm.net/resource centre/2018-09.pdf

[4] Ogbukagu, C.M., Anaukwu, C.G., Ekwealor, C.C., Mba, A.N. and Ekwealor, I.A. (2020) Physicochemical and Antibacterial Susceptibility Profile of Fish Pond Waters in Anambra State, Nigeria. American Journal of Microbiological Research, 8, 150-159. https://doi.org/10.12691/ajmr-8-4-5

[5] Adegunloye, D.V. and Sanusi, A.I. (2019) Microbiota of Catfish (Clarias gariepinus) Tissues Harvested from Vials Polluted with Soil from e-Wastes Dumpsite. International Journal of Fisheries and Aquaculture, 11, 104-111. https://doi.org/10.5897/IJFA2018.0718

[6] Fakorede, C.N., Fatokun, E.N., Philip-kantiok, B., Iwu, C.J. and Jaja, I.F. (2019) Bacteriological Assessment and Antibiotics Susceptibility Profile of Bacteria Recovered from Pond Water, Fish Skin and Gut in Ile-Ife, Osun State, Nigeria. Preprints. https://doi.org/10.20944/preprints201904.0108.v1

[7] Emikpe, B.O., Adebisi, T. and Adedeji, O.B. (2011) Bacteria Load on the Skin and Stomach of Clarias gariepinus and Oreochromis niloticus from Ibadan, South West Nigeria: Public Health Implications. Journal of Microbiology and Biotechnology Research, 1, 52-59.

[8] Yasin, R., Jabeen, F., Ali, M., Samiullah, K. and Makhdoom, S. (2018) Effects of Yeast (Sacchaoromyces cerevisiae) on the Intestinal Microbiota of GIFT Tilapia (Oreochromis mossambicus). International Journal of Biosciences, 12, 283-291. https://doi.org/10.12692/ijb/12.4.283-291

[9] Adams, M.R. and Moses, M.O. (2008) Food Microbiology. Third Edition, The Royal Society of Chemistry, Cambridge, 179.

[10] Ayeloja, A.A., George, F.O.A., Obasa, S.O. and Sanni, L.O. (2011) Effect of PostSlaughter Time Intervals on the Quality of the African Catfish, Clarias gariepinus (Burchell, 1822). American Journal of Food Technology, 6, 790-797. https://doi.org/10.3923/ajft.2011.790.797

[11] Abolagba, O.J. and Uwagbai, E.C. (2011) A Comparative Analysis of the Microbial Load of Smoke-Dried Fishes (Ethmalosa fimbriata and Pseudotolithus elongatus) Sold in Oba and Koko Markets in Edo and Delta States, Nigeria at Different Seasons. Australian Journal of Basic and Applied Sciences, 5, 544-550.

[12] Adebayo-Tayo, B.C., Odu, N.N., Igiwiloh, N.J.P.N. and Okonko, I.O. (2012) Microbiological and Physicochemical Level of Fresh Catfish (Arius hendelotic) from Different Markets in Akwa Ibom State, Nigeria. New York Science Journal, 5, 46-52.

[13] Afolabi, O.J., Oladele, O.O. and Olususi, F.C. (2020) Assessment of Bacterial Loads of Clarias gariepinus (Burchell, 1822) Obtained from Cultured and Natural Habitats. The Journal of Basic and Applied Zoology, 81, 365.

https://doi.org/10.1186/s41936-020-00168-w

[14] Newaj-Fyzul, A., Mutani, A., Ramsubhag, A. and Adesiyun, A. (2008) Prevalence of Bacterial Pathogens and Their Anti-Microbial Resistance in Tilapia and Their Pond Water in Trinidad. Zoonoses Public Health, 55, 206-213. https://doi.org/10.1111/j.1863-2378.2007.01098.x

[15] Ribeiro, R.V., Reis, E.M.F., Reis, C.M.F., Freitas-Almeida, A.C. and Rodrigues, D.P. (2010) Incidence and Antimicrobial Resistance of Enteropathogens Isolated from an 
Integrated Aquaculture System. Letters in Applied Microbiology, 51, 611-618. https://doi.org/10.1111/j.1472-765X.2010.02946.x

[16] Gufe, C., Hodobo, T.C., Mbonjani, B., Majonga, O., Marumure, J., Musari, S., Jongi, G., Makaya, P.V. and Machakwa, J. (2019) Antimicrobial Profiling of Bacteria Isolated from Fish Sold at Informal Market in Mufakose, Zimbabwe. Hindawi International Journal of Microbiology, 2019, Article ID: 8759636. https://doi.org/10.1155/2019/8759636

[17] Ojiako, J.C., Okafor, C.M. and Igbokwe, E.C. (2015) Geospatial Mapping of Fish Farms in Animal State Using GIS Approach. International Journal of Scientific and Engineering Research, 6, 42-53.

[18] Noel, K.R. and John, H.G. (1984) Bergey's Manual of Systematic Bacteriology. Barbara T. Edition, William and Wilkins Publishers, Baltimore, 85-115.

[19] Bauer, A.W., Kirby, W.M., Sheris, J.C. and Turck, M. (1966) Antibiotic Susceptibility Testing by Standardized Single Disc Method. American Journal of Chemical Pathology, 45, 493-496. https://doi.org/10.1093/ajcp/45.4 ts.493

[20] Clinical and Laboratory Standards Institute (CLSI) (2017) Performance Standards for Antimicrobial Susceptibility Testing. 27th Edition, Clinical and Laboratory Standards Institute, Wayne.

[21] Makori, A.J., Abuom, P.O., Kapiyo, R., Anyona, D.N. and Dida, G.O. (2017) Effects of Water Physicochemical Parameters on Tilapia (Oreochromis niloticus) Growth in Teso North Sub County, Busia County. Fisheries and Aquatic Sciences, 20, 30. https://doi.org/10.1186/s41240-017-0075-7

[22] Hossain, M.K., Islam, K.T., Hossain, M.D. and Rahman, M.H. (2013) Environmental Impact Assessment of Fish Diseases on Fish Production. Journal of Science Foundation, 9, 125-131. https://doi.org/10.3329/jsf.v9i1-2.14655

[23] Mgwede, C.W., Msiska, O. and Kapute, F. (2018) Comparative Assessment of Microbiological Safety of Fresh and Parboiled Engraulicypris sardella (Usipa) from Selected Selling Points in the City of Mzuzu, Malawi. MOJ Food Processing and Technology, 6, 355-360. https://doi.org/10.15406/mojfpt.2018.06.00187

[24] Sule, I.O., Agbabiaka, T.O., Ahmed, R.N., Saliu, B.K. and Olayinka, K.L. (2016) Bacteriological and Physicochemical Analysis of Waste Water from Fish Ponds. Ethiopian Journal of Environmental Studies and Management, 9, 167-178. https://doi.org/10.4314/ejesm.v9i2.5

[25] Abu, O.M.G. and Uwadirioha, U. (2016) Comparative Study on Bacterial Load in Intestine, Gills and Skin of Cultured African Catfish (Clarias gariepinus) from Different Locations in Rivers State, Nigeria. International Journal of Innovative Studies in Aquatic Biology and Fisheries, 2, 21-29.

https://doi.org/10.20431/2454-7670.0203004

[26] Bekele, B., Workagegn, K.B. and Natarajan, P. (2019) Prevalence and Antimicrobial Susceptibility of Pathogenic Bacteria in Nile Tilapia, Orechromia niloticus L. International Journal of Aquaculture and Fishery Sciences, 5, 22-26. https://doi.org/10.17352/2455-8400.000047

[27] Al-Harbi, A.H. and Uddin, M.N. (2010) Bacterial Populations of African Catfish Clarias gariepinus (Burchell 1822) Cultured in Earthen Ponds. Journal of Applied Aquaculture, 22, 187-193. https://doi.org/10.1080/10454438.2010.497736

[28] Ajani, E.K., Orisasona, O. and Omitoyin, B.O. (2015) Comparison of Bacterial Flora and Frequency of Occurrence in Water and Clarias gariepinus Raised in Ponds Fertilized with Raw Poultry Manure. Journal of FisheriesSciences.com, 10, 16-21.

[29] Naim, U. and Al-Harbi, A.H. (2012) Bacterial Flora of Polycultured Common Carp 
(Cyprinus carpio) and African Catfish (Clarias gariepinus). International and Aquatic Research, 4, Article No. 10. https://doi.org/10.1186/2008-6970-4-10

[30] Akaniro, I.R., Anumudu, O.H., Oweredaba, C.I., Koledowo, A.K., Egboka, K.C. and Ofonegbu, M.N. (2020) Isolation, Characterization and Antibiotic Resistance Profile of Bacteria from the Gut of African Catfish, Clarias gariepinus. Journal of Scientific and Engineering Research, 7, 188-195.

[31] Abdel-Salam, S.S., Ghaly, F.M., Baraka, D.M., Mahmoud, S.H. and El-Makhzangy, A.A. (2016) Isolation and Identification of Bacterial Flora from Catfish (Clarias gariepinus) with Antimicrobial Susceptibility and Herbal Sensitivity. Journal of Pure and Applied Microbiology, 10, 1835-1846.

[32] Ayandiran, T.A. and Dahunsi, S.O. (2017) Microbial Evaluation and Occurrence of Antidrug Multi-Resistant Organisms among the Indigenous Clarias Species in River Oluwa, Nigeria. Journal of King Saud University-Science, 29, 96-105. https://doi.org/10.1016/j.jksus.2016.02.001

[33] Hany, M.R., Abdel-Latif and Sedeek, E.K. (2017) Diversity of Enterobacteriaceae Retrieved from Diseased Cultured Oreochromis niloticus. International Journal of Fisheries and Aquatic Studies, 5, 29-34.

[34] Tsfaye, S., Kasye, M., Chane, M., Bogale, B. and Abebeagre, Z. (2018) Preliminary Survey of Gram-Negative Bacterial Pathogens from Commonly Caught Fish Species (Oreochromis niloticus, Cyprinus carpio and Clarias gariepinus) in Lake Hayiq, Ethiopia. Fisheries and Aquaculture Journal, 9, Article ID: 1000238. https://doi.org/10.4172/2150-3508.1000238

[35] Al-Harbia, A.H. and Naim Uddina, M. (2011) Aerobic Bacterial Flora of Common Carp (Cyprinus carpio L.) Cultured in Earthen Ponds in Saudi Arabia. Journal of Applied Aquaculture, 20, 108-119. https://doi.org/10.1080/10454430802197292

[36] Austin, B. (2002) The Bacterial Microflora of Fish. The Scientific World Journal, 2, 558-572. https://doi.org/10.1100/tsw.2002.137

[37] Deng, D., Li, Y., Geng, Y., Zheng, L., Rehman, T., Zhao, R., Wang, K., Yang, P.O., Chen, D., Huang, X., He, C., Yang, Z. and Lai, W. (2019) Molecular Serotyping and Antimicrobial Susceptibility of Streptococcus agalactiae Isolated from Fish in China. Aquaculture, 510, 84-89. https://doi.org/10.1016/j.aquaculture.2019.05.046

[38] Osman, K.M., Ali, M.N., Radwan, I., ElHofy, F., Abed, A.H., Orabi, A. and Fawzy, N.M. (2016) Dispersion of the Vancomycin Resistance Genes vanA and vanC of Enterococcus Isolated from Nile Tilapia on Retail Sale: A Public Health Hazard. Frontiers in Microbiology, 7, Article No. 1354. https://doi.org/10.3389/fmicb.2016.01354

[39] Rahman, M., Rahman, M.M., Deb, S.C., Alam, M.S., Alam, M.J. and Islam, M.T. (2017) Molecular Identification of Multiple Antibiotic Resistant Fish Pathogenic Enterococcus faecalis and Their Control by Medicinal Herbs. Scientific Report, 7, Article No. 3747. https://doi.org/10.1038/s41598-017-03673-1 